\title{
The Boundary of Confucianist: the Excellence in Both Moral Character and in Governing
}

\author{
Zhang Xiaofang \\ Jiang Xi Technician College, Nan Chang Jiang Xi 330200, China
}

\begin{abstract}
The excellence in both moral character and in governing" is "the morality moral character" cultural manifesting, is the pursue "the beauty gathers one" mind boundary. The Confucianist "the excellence in both moral character and in governing" is "gathers from the beauty one” internalizes is "the beauty gathers Germany" the beginning, after outside human's disposition tutelage king world, namely “excellent in both moral character and in governing” complacent self sufficient, finally returns again turns over to gather a ideal to the beauty. This article is for the purpose of explores the Confucianist core proposition "the excellence in both moral character and in governing" the true meaning, seeks for advice the side.
\end{abstract}

Key word - The beauty gathers one, The beauty gathers Germany, Excellence in both moral character and in governing, Boundary

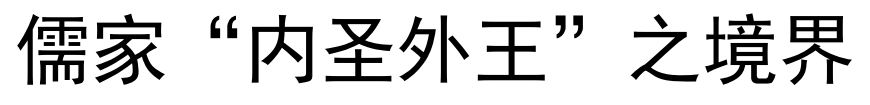

\author{
张小芳 \\ 江西技师学院, 南昌, 江西, 中国
}

\begin{abstract}
摘 要 “内圣外王” 是 “德性” 文化的体现, 是追求 “天人合一” 的心灵境界。儒家 “内圣外王” 是从 “天人合一” 内化为 “天 人合德” 始, 中经人的心性修养外化出王者天下, 即 “内圣外王” 的自满自足, 最后再返归到天人合一的理想。本文旨在探索儒家核 心命题 “内圣外王”的真谛, 以求教方家。
\end{abstract}

关键词 天人合一, 天人合德, 内圣外王, 境界

“内圣外王” 最早出现于《庄子 - 天下篇》: “生, 王 有所成, 皆原于一 (道)”, 此即 “内圣外王之道”。它表现 为: “不离于宗, 谓之天人, 不离于精, 谓之神人; 不离于 真, 谓之至人。以天为宗, 以德为本, 以道为门, 兆于变 化, 谓之圣人, 以仁为恩, 以义为理, 以礼为行, 以乐为 和, 熏然慈仁, 谓之君子”, “是故内圣外王之道, 闇而不 明, 郁而不发, 天下之人各为其所欲焉以自为方。” 此 “道” 以天地为宗, 以道德为本, 涵盖宇宙整体, “夫道, 覆载万 物者也, 洋洋乎大哉!”, “故通于天地者, 德也; 行于万物 者, 道也。” (《庄子. 天地篇》), 只有天人、神人、至人、 圣人具备 “内圣外王” 理想人格, 故能体认 “内圣外王” 之道, 随着时间的演绎变迁, 成为多家学派思想相结合的 产物。

虽然 “内圣外王” 不是儒家最先提出来的字眼, 但却 代表了儒家的核心精神, 尤其宋代以来被芼释得最为到位,
并成为儒学的基本命题。其内涵通俗的讲, “内圣” 是正心、 诚意、格物、致知, “外王” 则是齐家、治国、平天下; 其 过程不是直通, 也不是自然延接, 是通过渐修实践来得以 实现, 是 “明明德, 止于至善” (《大学》) 和治世功业, 圣 人理想人格的概括。既体现 “王者” 的人格理想的修炼,

又体现 “王者” 的王道追求的境界。一语括之, “内圣外王” 是 将内在于个体的 “天之道” 完美的道德人格, 转化为圣 人的王道理想, 最终通过天与人合、人与天合、天人一体 一气, 最终归于统一, 进入治国平天下的圣王境界。

1. “天人合一” 内化为 “天人合德”

“天人合一” 是儒学的基本命题, 也是儒家所追求的 最高境界, 体现出 “有机宇宙哲学 (李约瑟语)” 的思维方 式, 这是以人文主义为前提的, 人 “为天地立心, 为生民 立命, 为往世继绝学, 为万世开太平” (《张子语录》卷中)。 
人立于天地之间与天地并存。儒家哲学对天地自然有一套 独特的看法, 认为天生万物都是为了人, 即所谓 “天生之, 地养之, 人成之” ( [清]苏與撰《春秋繁露义证 - 立元神》)。 把自然看成是大化流行的有机整体, 并有着高尚的道德情 感, 可以与人发生感应共鸣, 表现了一种 “天人合德” 的 价值取向。

这就清楚的表明, 其价值取向把 “天人合一” 拔高为 道德境界, 探求个体人格与社会道德的统一, 传递出 “天 人合德” 精神气度, 天人能够合一的内核便是 “德”, 从天 地之道引出立人之道, 以天人同构为 “天人合一” 提供依 据, “德” 作为精神价值的体现, 源于 “天”, 《易传》: “天 地之大德曰生”, 即所谓生生之德, 为天地之最, 通过品物 流行, 化成天下万物, 成就人的德性, 最终以天合人。“以 天合人” 标明儒家 “天人合一” 境界和精神, “德” 作为天 地精神体现, 人可以取其精华消融于天地之间, 与天地合 其德, 至天人合一宇宙道德境界, 实现天人价值统一。然 而 “德” 作为精神形而上是寓于人心之中, 是一种内在的 形而上实体，只有修身成已不断自我超拔，使之外化现实， 达至齐家、治国、平天下。故 “夫大人者，与天地合其德， 与日月合其明, 与四时合其序, 与鬼神合其吉凶。” (《周 易・乾卦・文言》), 从天道运行规律出发, 向往天道维度, 阐释 “德” 能覆载万物, 与日月齐辉, 与四时交替合拍, 与吉凶契合, 从而个体生命与宇宙生命融为一体, 上达 “天 德”, “德配天地” 《庄子 - 田子方》, 最终与天合, 达至天 人合一境界。天、地、人、德围绕一个主题: “天行健, 君 子以自强不息, 地势坤, 君子以厚德载物。” (《易传 • 象辞》)。 “自强不息”, “厚德载物” 成就于圣王理想品格。既有源 于天创生不息的原动力, 又有大地的博厚, 容载万物, 既 能 “已欲立而立人, 已欲达而达人” (《论语 - 雍也》)。又 能 “仁者爱人” (《论语 - 颜洲》), 在天、地、人之中孜孜 以求人格的最终实现, 天作为价值的源头, 人是价值载体, 天道内化为人心, 人心外显于天道。“天下归仁”, (《论语 颜 渊》)。“仁者, 人也”，(《中庸》)。“仁” 是儒家的基石和人 性的最高境界, 圣人之心与天道相通, “化天志而仁, 化天 理而义”。（董仲舒《春秋繁露・为人者天》), 将天理、 天意内化于仁、义之中, 再由 “仁” 外推出圣人不违 “天 命”, “上达” 于 “天命”, 达至与天同为一体, 实现 “天人 合一”。

对此, 宋儒挖掘较深, 其以为 “圣人尚公尚同, 圣人 之心, 与天为一, 无我至公, 以一已之 “公心” 发而 “感 天下之心” ”[1], 正如子曰: “圣人公心, 尽天地万物之理”, 所谓天有 “好生之德”, (《尚书 - 大禹谟》), 圣王则天, 其 实质将个体德性本原于天, 再复归于天, 最终圣人之道与 天道达成一致, 就其最终落脚于 “德”, 至此, 天、德在本
体层面合一, 实现人与天、人与人、人与我和谐, 即 “内 圣”。进而在其基础上由内向外推, 把自我价值付诸实践。 由已及人, 用内修去感化百姓, 使自己的言行作为价值原 则贯彻对社会起价值导向作用, 在认识尽心、知性、达至 通天。在人的践形整体活动中, 内省与外求, 情与理, 知 与行的统一中达到赞化育, 参天地与天地同流的最高境界, 即天人合一, 其实质上是天人合一内化为内圣外王的过程。 故天至善、至德, 人与天地并生, 与万物同一, 人与天同 承 “天地位焉, 万物育焉” 的天地万物之道, 这便是真正 意义上的 “内圣外王”之道。

\section{2. “内圣外王”的自满自足}

内圣是作为形而上之体, 外王则是形而上之用, 是内 修与外化的辩证统一, 内圣作为道德的理想境界是一种内 在的德性自觉, 外王以德性形而上之修成而展显出来的事 功, 即内圣是体, 外王是用。故《大学》曰: “古之欲明明 德于天下者, 先治其国, 欲治其国者, 先齐其家, 欲齐其 家者, 先修其身, 欲修其身者, 先正其心, 欲正其心者, 先诚其意, 欲诚其意者, 先致其知, 致知在格物。” 充分展 示内圣外王即是心性修养的过程, 无论是 “修已以安百姓”, (《论语・宪政》)。还是 “有不忍人之心, 斯有不忍人之政” 《孟子 - 公孙丑上》, 都是用心性修养之体与外在事功之用 加以揉合, 将仁政构筑于人的善性当中, 善的积累便成就 圣心, 所谓 “积善成德, 而神明自得, 圣心备焉” (《荀子・劝 学》)。

正是如此, 孟子从人性本善出发, 将内圣达之外王之 功用, 再用 “民贵君轻” 为政之理反证善的价值。把心性 修养和为政之道一并提升, 达到本然的契合, 进而 “万物 皆备于我也, 反身而诚”, (《孟子・尽心上》), 强化个体伦 理责任, 并以此增强伦理信念, 以善作依托, 推行 “不忍 人之政” 心性修养与内圣外王相结合的思维模式, 用性扩 张善, 反身求诚, 返归本心, 最终超拔本心, 通过 “存心”、 “养性”、“尽人之性, 尽物之性”, “格物致知”上升到 “诚 意正心” 的道德意志, 开创 “修身——齐家——治国—— 平天下” 的内圣外王之道, 心性修养基石为 “仁”, “凡人 之性, 莫贵于仁” (《淮南子》)。这便是儒家 “仁” 的本意。 其人性修养也称 “体道返性”, 只不过 “道” 归于 “仁” 罢 了, 故《孟子・尽心下》曰: “仁也者, 人也, 合而言之, 道也。” “仁” 囊括了天道、地道、人道各方面, 上承天, 下形地, 充实于人的主体中, 人的价值在于实践 “仁”。

“仁” 儒家思想的精髓, “仁” 字早在甲骨文时代就有, 《说文解字》曰: “仁, 亲也, 从人从二”, 《说文通训定声》 释曰: “仁者, 情志好生爱人, 故立字二人为仁”, 儒家强 调 “仁”, 并作为本体对待, 子曰: “克已复礼为仁, 一曰 
克已复礼, 天下归仁焉, 为仁由已, 而由人乎哉? ” (《论 语 - 颜波》)。由此推知, “仁” “洋溢着一种始源于天道生 生不息的刚乾精神” [2], “仁” 具有情感性特征, 是人 发自内心的抉择, 更是一种切身的了悟与成圣殊途同归。 “内圣” 最高境界在于 “仁”, 由 “仁” 而 “圣” 是辩证提 升, 正如所谓 “仁者安仁, 智者利仁, 君子无终食之间违 仁” (《论语 - 里仁》)。“仁” 首先是片刻不离的道德品性视 一般要求, 而 “无求生以害仁, 有杀身以成仁”, (《论语・卫 灵公》)。至此 “仁” 已不是一般标准, 而是成圣最高需求, “仁者” 的无私忘我、积极性与 “圣人” 所求 “博施于民 而能济众” (《论语 - 雍也》) 的情怀没有区别, 将仁者与圣 人归为一体。

“仁” 向外求的更高标准便是 “爱人”, “仁者, 爱人”, (《论语・ 颜滟》)。“唯仁者能好人, 能恶人” (《论语 - 里 仁》)。“成仁” 是归于 “道”, 是外王的最高标准, 即是行 “仁政”, “仁政” 便由里而外将内圣外王贯通, 因为心性 修养最高境界只能为内圣, 必须只有兼济天下, 将个体人 格升华济世理想人格, 将仁德内化与外推合二为一的圆满 境界, 达至内圣外王真正统一。内圣为基础, 外王为目的, 只有寻求内心的不断修养, 在其基础之上安邦治国, 才能 达到外王的目的, 是一个内在统合过程, 内圣通达外王才 有意义; 外王的实现, 最终促进内圣的完成。

子曰: “夫仁者, 已欲立而立人, 已欲达而达人,” (《论 语 - 雍也》)。“欲” 贯通内外, 立已、达已是基础, 立人达 人是归宿, “立已” 为体, “达人”为用, 体用统一。《礼记 -大 学》曰: “物有本末, 事有始终, 知所先后, 则正道矣。” 内圣外王的 “本” 则是圣人内修, 即心性修养, 内圣是正 心、诚意、格物、致知, 外王则是齐家、治国、平天下, 起点在个体自我, 终点政伦合一, 达至 “致中和, 天地位 焉, 万物育焉”。(《中庸》)。至此, 内圣外王便自满自足。

\section{3. “内圣外王” 返归到 “天人合一”}

儒家习惯以诚说性, 贯通天道与人道, 以 “人道” 释 说 “天道”, 然后 “人道” 又本于 “天道”, 彰显于 “天道” 变化产生的结果, “人道” 的人伦日用与 “天道” 阴阳变化 一致, 其相通合于 “诚”。故《孟子・离娄上》曰: “诚者, 天之道也, 思诚者, 人之道也。” 将 “诚” 升华为 “天道”, “思诚者” 升华为 “人道”, 故《正蒙. 乾称》 “儒者明致 诚, 因诚至明, 故天人合一”。从认识论出发, 以明致诚, 再因诚反求明, 达至认识主体内外统一。““诚” 来自于天 与人的主体的统一性, 来自于天道、人道的摩荡, 互渗,
是天与人的 “至诚” 之德的混冥之体激发、唤醒、感化, 最终成就万事、万物生发、发展、提升和完善” [2]。“诚” 作为纯粹理念, 是人道、天道的最高境界, 终结于人性的 最终实现, 天人合一的基础, 而且尽已之性成已, 尽物之 性成物, 尽物之性则赞天地之化育, 赞天地之化育则与天 地参焉。

诚为德本, 作为道德的本体, 其修为则正如王夫之曰: “欲致其诚者, 惟在于操存, 勿使间断……”, 不断感物化 俗渐进, 最终成圣成王, 然而 “圣贤非性生, 必养心而至”。 故《孟子 - 尽心上》: “尽其心者, 知其性也, 知其性, 则 知天矣, 存其心, 养其性, 所以事天也。”从人心本于性而 受于天出发, 天作为心的终极依据, 是人伦道德的本原。 外化为人的心性、德性。天道展开为人道, 人道通归于天 道, 人道天道一体, 圣人通过反观、内省自身的心性, 求 得知性、知天, 从而超拔自然境界、功利境界和道德境界。 进而 “尽心” “知性”、 “知天”, 从而成为人伦之至的圣人。 “诚者, 圣人之本”, (周敦臨《通书・诚上第一》)。诚者 等同于圣也, 只有圣人才能将主客体融为一体, 泯灭心物 之间的畛域立诚, 立人道, 立天道, 诚在人性之中贯通天 道诚体, 故诚为中介, 达至天地人、天人物统一。即内圣 的诚德为外王的践履, 至此才能成就他人、万物的道德, 对事物本性无所不悉, 由此赞天地自然之化育, 天人地并 立为三, 天人合一。

内圣外王是 “德性” 文化的体现, 是追求 “天人合一” 的心灵境界, “格物、致知、诚意、正心、修身、齐家、治 国、平天下。”此乃内圣外王一体, 在公平与正义的政治框 架下, “德治” 不容忽视, 同样一个真正民主政治社会, 要 对人性的循循善诱, 道德修为的倡导, 新时代新道德基础 的建立，应该用 “主体意识、公民意识和民主意识代替无 我意识、臣民意识和圣王意识” [3]赋予内圣外王崭新意义, 内圣开出外王, 其任重亦道远矣。

\section{参考文献(References)}

[1] LiDongjun. "Confucius sanctification and Confucian revolution". Page247. Renmin University of China press 2004

[2] OuYangZhenren. "The pre Qin Confucian thought of nature". Page2.398. Wuhan University press.2006

[3] Zhu Weizheng. "Confucianism and the future society". Shanghai people's press, 1991 